\title{
Историко-географическое исследование Дальнего Востока России
}

\author{
А. А. Ахременя $ه$ \\ Забайкальский государственный университет, Российская Федераиия \\ (672039, г. Чита, ул. Александро-Заводская, 30)
}

\begin{abstract}
Аннотация: Цель данного исследования - проведение историко-географического анализа Дальнего Востока России, выявление особенностей формирования специализации и демографических процессов в регионе.

На каждом историческом этапе политика региона претерпевала изменения в социальном развитии, подстраивалась под изменяющиеся экономические и геополитические условия, а также политику центра. В настоящее время развитие Дальнего Востока выступает приоритетным направлением внутренней политики нашей страны, поэтому издаются специальные нормативно-правовые акты, создано Министерство, лоббирующее интересы региона.

Основным сдерживающим развитие региона фактором можно считать кардинально различный уровень жизни населения на всем его пространстве, который предполагает нахождение оптимальной формы расселения жителей и пространственной организации, определение источников, способствующих росту численности, и условий, обеспечивающих приток населения.

Meтоды и материалы: сравнительно-географический, описательный, аналитический, индуктивный, математический, статистический, картографический.

Материалами исследования выступают статистические данные Росстата, литературные источники, фонды.

Ключевые слова: Дальний Восток, проблемы Дальнего Востока, дальневосточный гектар, природные ресурсы Дальнего Востока, территории опережающего развития.

Для цитирования: Ахременя А.А. Историко-географическое исследование Дальнего Востока России // Вестник Воронежского государственного университета. Серия География. Геоэкология, 2020, № 3, c. 61-71. DOI: https://doi.org/10.17308/geo.2020.3/3025
\end{abstract}

\section{ВВЕДЕНИЕ}

Дальневосточный регион в настоящее время включает в себя 11 субъектов Российской федерации. Анклавность географического положения способствовала зарождению представлений о проблемах в развитии экономики практически с самого начала освоения территории. В разные исторические периоды происходило чередование подъема и упадка экономики, успешное развитие региона зависело от социальной и экономической автономии, либо от наличия финансовых ресурсов, направляемых государством централизованно для решения приоритетных геополитических задач на востоке страны.

В настоящее время Дальний Восток - это тренд, объявленный государством на весь XXI век. Разработкой долгосрочных и последовательных планов по развитию региона занимается отдельное министерство, основанное в 2012 году - Министерство Российской Федерации по развитию Дальнего Востока и Арктики. За весь период его функционирования подготовлено и принято множество нормативно-правовых актов, направленных на поддержку населения, развитие социальной сферы и экономики региона.

Цель исследования - проведение историко-географического анализа Дальнего Востока России, выявление особенностей формирования специализации и демографических процессов в регионе.

\section{Период Российской империи}

История экономического и политического освоения Дальнего Востока началась со времени выхода Российской империи к Охотскому морю, где в 1647 году был основан Охотский острог. В

(C) Ахременя А.А., 2020

\ Ахременя Анастасия Алексеевна, e-mail: ahri @mail.ru

(c) (i) Контент доступен под лицензией Creative Commons Attribution 4.0 License. 
1858 году в состав Российской империи вошло Северное Приамурье, а в 1859 году - Уссурийский край, расширив территории Восточно-Сибирского генерал-губернаторства. Таким образом, можно считать, что именно с этого момента началась системная деятельность по экономическому освоению региона и капитализация тихоокеанского статуса России.

До 1880-х годов Дальний Восток рассматривался скорее, как военная колония, где доминирующим фактором была казачья колонизация. С 1880-х годов регион стал рассматриваться как земледельческая колония, основной задачей встало крестьянское переселение. После установления государственной границы с Китаем были приняты «Правила для поселения русских и иностранцев в Амурской и Приморской областях», составленные генерал-губернатором Восточной Сибири графом Н. Н. Муравьевым-Амурским и утвержденные 26 марта 1861 года [1]. Согласно этим правилам, в южные земли Дальнего Востока привлекались люди, которые могли бы содействовать экономическому развитию края и не требовали бы от правительства дополнительных средств на организацию переселения. То есть в Приамурье нужны те, кто обладает собственными средствами и готов идти на риск, переселяясь на необжитые земли.

Какие же льготы, в свою очередь, предполагались переселенцам? Согласно этим правилам: максимальная величина земельного надела на семью составляла 100 десятин (1 десятина=1,09 гектара), освобождение от податей и рекрутской повинности, выдача ссуд, обеспечение продовольствием [7]. Переселенцам была дана свобода в учреждении заводов и фабрик, ведении торговли на всей территории генерал-губернаторства. Бесплатной раздачи земли не было, у переселенцев была возможность выкупа земли в собственность по цене 3 рубля за десятину и рассрочкой выкупа на 20 лет [6].

Но перечисленные мероприятия не привели к массовому увеличению численности крестьянского населения на Дальнем Востоке. Во-первых, высока конкуренция со стороны более привлекательных для переселения Предкавказья, Предуралья и Степного края. Во-вторых, отсутствие развитых путей сообщения. В-третьих, отсутствие материального пособия за переселение. Большинство переселенцев оседало на полпути - в Западной Сибири и Оренбургской области. Большинство переселенцев упрочило свое хозяйство спустя 1520 лет. Здесь отдельно следует сказать об общине старообрядцев, основавших селение Толстовка, которое достигло благополучия уже через 3 года после переселения, ввиду отсутствия пьянства и большого количества церковных праздников.

Ситуация меняется в 1880-х годах, когда приоритетом становится крестьянская колонизация территорий Дальнего Востока. В 1882 году выходит закон, сохранивший все льготы из Правил 1861 года, с некоторыми поправками и добавлениями, в числе которых сохранение нормы максимального надела земли на семью в 100 десятин, введение минимального надела на душу - в 15 десятин, с правом выкупа по 3 рубля за десятину. Закон предоставлял переселенцам освобождение на родине от всех недоимок, государственных податей на 5 лет, даровой проезд по морю из Одессы во Владивосток, продовольствие на 1,5 года, 100 рублей на материалы для строительства жилья, пару лошадей или быков, одну корову, семена для посевов, предметы хозяйственного быта. Опять же ожидания не оправдались, предполагалось переселить 21 тысячу крестьян по морю, а по факту в 1894-1897 годах переселилось 11296 человек [4].

Данный закон претерпел изменения в 1892 году - полностью запрещая продажу земли иностранным подданным и определяя максимальный размер участка, отдаваемого в одни руки - в 400 десятин. Численность населения региона в 1896 году превысила 1 млн. человек [10].

В 1884 году образовано Приамурское генералгубернаторство, в состав которого вошли Амурская, Приморская, Забайкальская области, последняя в 1906 году была передана в состав Иркутского генерал-губернаторства. Стоит отметить, что Приамурское генерал-губернаторство было самостоятельным объектом государственного регулирования, к тому же вплоть до 1911 года генералгубернатор был высшим военным и гражданским начальником, то есть наместником императора. Канцелярия Приамурского генерал-губернаторства была немногочисленна, но весьма эффективна. Этому способствовало привлечение к подготовке управленческих решений неформальных организаций, таких как научные общества и объединения предпринимателей. Общество изучения Амурского края, Приамурский отдел Императорского Русского Географического Общества служили площадками для обсуждения проблем экономического развития региона. Материалы совещаний публиковались и были общедоступны. Например, перед строительством Амурской железной дороги была организована Амурская экспедиция в 
1910 году с привлечением специалистов науки. На строительство железных дорог и портов, а также на рыбные и лесные промыслы в 1907 году в Приморскую область прибыло 61722 человека, в Амурскую - 11782 человека [12].

После русско-японской войны и до установления советской власти будущее Дальнего Востока связывалось с развитием промышленности, так как было произведено исследование месторождений полезных ископаемых. Таким образом, до советизации Дальний Восток - территориальная социально-экономическая система с диверсифицированной и быстрорастущей экономикой, активно взаимодействующая с экономиками сопредельных стран.

\section{Период Советской власти}

Приамурское генерал-губернаторство было упразднено в 1917 году. После этого территориальное деление советского Дальнего Востока претерпевало множество изменений. Так, в период с 1922 по 1924 год существовала Дальневосточная область с административным центром в городе Чите.

До 1930-х годов экономика Дальнего Востока оставалась аграрной при статусе региона как бюджетно-финансовой автономии. Поэтому в 1930 году были приняты постановления ВЦИК и Политбюро ВКП(б) о развитии Дальнего Востока, в которых была поставлена задача обеспечения высоких темпов развития промышленности ради создания автономного экономического комплекса, способного обеспечить армию и флот в тылу при военном конфликте. С 1932 года было инвестировано свыше 7 млрд. рублей в такие отрасли экономики как судостроение, химия, энергетика, нефтепереработка, топливная промышленность и цветная металлургия. Благодаря чему объем промышленного производства увеличился более чем в 3 раза, что позволило называть Дальний Восток индустриальным регионом, с долей промышленности в валовом продукте свыше $80 \%$. Регион требовал большого количества рабочей силы. Власти прибегали к насильственному перемещению, главным образом заключенных, которых только по морю было перевезено более 1 млн. человек.

В 1938-1942 годах предполагалось продолжить ускоренное развитие Дальнего Востока. Начало войны принципиально не затронуло темпы развития экономики. Лишь возросла добыча золота, вольфрама, молибдена, нефти. Численность населения превысила 4 млн. человек.
После войны произошло переориентирование ресурсов на восстановление европейских регионов. Дальний Восток потерял особый институциональный статус, а с ним и приоритет в централизованных ресурсах, и возможность использовать внешнеторговые доходы в качестве ресурсов накопления. Похожая ситуация была в 1920-е годы, но тогда «анклавность» экономики компенсировало централизованное финансирование. Именно в этот период зародилось представление о нарастающих проблемах в экономике Дальнего Востока из-за нехватки ресурсов для комплексного развития.

С 1920-х годов централизованное планирование основывалось на концепции районирования, согласно которой экономические районы трактовались как хозяйственные комбинаты, т.е. экономический район - это совокупность пропорционально развивающихся на территории отраслей хозяйства. В 1950-х годах возник так называемый экономический барьер на границе с Сибирью изза конкурентности, а также ограниченность в использовании внешнего рынка привели к диспропорциям, в числе которых концентрация ресурсов в отраслях специализации и как следствие, ограниченное развитие комплексных производств и инфраструктуры. Выход из сложившегося положения был в восстановлении элементов модели регионального развития 1920-х годов, когда внешний спрос определял масштабы и структуру экономики Дальнего Востока. Свое предложение по развитию экономики региона внес экономист Василий Сергеевич Немчинов, главной идеей которого являлось привлечение инвестиций из-за границы, что было сформулировано в концепции экспортной специализации [11]. Как и в 1920-е годы для региона была создана ситуация «особого» экономического района. Иностранные инвестиции на Дальний Восток привлекались в форме компенсационных соглашений, стимулировавших развитие лесопромышленного, рыбного, угольного и газодобывающего комплексов.

В середине 1960-х годов обострилась угроза военного конфликта с Китаем, поэтому была восстановлена приоритетность в распределении централизованных капиталовложений в развитие тяжелой промышленности, создание оборонных предприятий и инфраструктуру региона. Стоит упомянуть строительство БАМа - военно-структурного проекта, обосновывающегося как программа экономического освоения новых территорий. Это вызвало новую волну переселения на Дальний Восток. 
В 1980-е годы экономика Дальнего Востока представляет собой диверсифицированный комплекс, в составе которого выделяются отрасли промышленной специализации, доля экспорта составляет $3,8 \%$, главным образом, это круглый лес, целлюлоза, рыбопродукция; значительную долю оборудования и сырья составляет импорт.

Таким образом, история показывает, что регион успешно развивался либо, когда анклавность дополнялась экономической и социальной автономией, как в 1920-е, либо компенсировалась ролью региона в решении геополитических задач страны, что вызывало патронат со стороны государства, как в периоды 1860-1916, 1930-1945, 19651980 годов.

Советская эпоха для Дальнего Востока завершилась последней попыткой «спасти» хозяйственный комплекс региона - «поворотом на Восток» после речи Михаила Сергеевича Горбачева в 1986 году во Владивостоке, объявившим курс на интеграцию с тихоокеанскими экономиками. Главной задачей было превращение Дальнего Востока в экономический и торгово-финансовый плацдарм СССР на Тихом океане. Для этого в 1987 году принята Долговременная государственная программа комплексного развития производительных сил Дальневосточного экономического района, Бурятской АССР и Читинской области на период до 2000 года. Программа предполагала ряд стимулов. Например, создание совместных предприятий, налоговые льготы для иностранных инвесторов, выделение части таможенных доходов в пользу дальневосточных регионов. Ввиду политических событий, программа вместо положенных 15 лет действовала всего 5. Наметившийся к 1990 году в экономике всей страны спад начался и на Дальнем Востоке, где уменьшилась добыча угля. Ввод энергомощностей составил лишь $30 \%$ от планируемого, сорвана добыча углеводородов на шельфе, дефицит местных бюджетов составил $40 \%$ [8]. Наиболее критическими проблемами для региона стало разрушение системы гарантий государственного спроса в тяжелой и оборонной промышленности, сокращение военной группировки на Дальнем Востоке, приостановка льготных режимов, сокращение финансовой поддержки государства, отказ государства от признания Дальнего Востока приоритетным регионом с точки рения распределения ресурсов и статуса населения.

Можно сделать вывод, что чередование фаз «государственный патронат - автономия» является показателем важности для государства решений проблем геополитического и социально-экономического плана на Дальнем Востоке. Если на первый план выходят геополитические задачи страны, то развитие региона становится приоритетным в системе распределения бюджетных ресурсов. В случае снижения геополитической напряженности на Дальнем Востоке вектор внимания государства и финансовые ресурсы направляются на иные приоритеты, а регион остается представлен себе самому или экономика региона остается на задворках ввиду ресурсоформирования в других регионах.

\section{Новейший период}

Одновременно с упадком экономики происходил отток населения, начавшийся в 1980-е и резко усилившийся после 1992 года. Это послужило одним из факторов восстановления государственного патроната над Дальним Востоком, кроме которого толчком было и опасение «желтой аннексии», и страх перед сепаратизмом [9]. Как следствие, в апреле 1996 года была принята новая государственная программа «Экономическое и социальное развитие Дальнего Востока и Забайкалья на 19962005 годы», но ее постигла та же судьба, что и предшествующую программу 1987 года, в связи с экономическим кризисом 1998 года. Новый вариант программы был принят в 2002 году с пролонгацией ее до 2010 года. Такие программы появлялись постоянно - 2007, 2014, 2016 годы и имели весьма опосредованное отношение к решению проблем региона.

Многие проблемы региона были смягчены в 2000-2008 годах. Так, Дальний Восток из энергодефицитного стал энергоизбыточным, ввиду ввода новых мощностей, строительства инфраструктуры для добычи углеводородов на Сахалине; модернизация Транссиба и БАМа, корректировка железнодорожной политики, развитие морских портов улучшили транспортную инфраструктуру; быстро развивался экспортный сектор экономики.

За последние 15 лет Дальний Восток стал нефтеэкспортирующим регионом, $99 \%$ его экспорта сконцентрировано на сырьевой специализации. За рубеж регион поставляет топливные и лесные ресурсы, металлические руды, продукцию цветной металлургии, рыбопродукцию. Сферы инвестирования в регионе разделены рационально: концентрация государственных бюджетных средств происходит в инфраструктурном сегменте, а частных - в сегменте добычи и экспорта природных ресурсов. Что касается оттока населения, то это фактор не только дальневосточный (таблица). 
Динамика численности населения РФ (без Крыма) 1991, 2015 (млн. чел.) [13, 14]

[Table. Dynamics of the population of the Russian Federation (excluding Crimea) 1991, 2015 (million people)]

\begin{tabular}{|l|c|c|c|}
\hline $\begin{array}{c}\text { Федеральный округ/ } \\
\text { Federal District }\end{array}$ & 1991 & 2015 & $\begin{array}{c}\text { Прибыль/убыль } \\
\text { Profit/loss } \\
+/-\end{array}$ \\
\hline Центральный & 38,1 & 39,1 & $+1,0$ \\
\hline Северо-Западный & 15,2 & 13,8 & $-1,4$ \\
\hline Поволжский & 31,9 & 29,7 & $-2,2$ \\
\hline Южный & 13,6 & 14,0 & $+0,4$ \\
\hline Северо-Кавказский & 6,6 & 9,7 & $+3,1$ \\
\hline Уральский & 12,7 & 12,3 & $-0,4$ \\
\hline Сибирский & 21,1 & 19,3 & $-1,8$ \\
\hline Дальневосточный & 8,05 & 6,2 & $-1,85$ \\
\hline РФ в целом & 147,2 & 144,1 & $-3,1$ \\
\hline
\end{tabular}

Изменение структуры экономики в 1990-х годах, стремление к защите личных имущественных прав в государствах - бывших республиках СССР, потеря уверенности в гарантии созданных на Дальнем Востоке накоплений для жизни в будущем стали причинами оттока населения с Дальнего Востока.

Экономика Дальнего Востока имеет возможности для развития на основе имеющихся богатых природных ресурсов и близости с динамично развивающимися странами АТР.

В мае 2012 года создается Министерство по развитию Дальнего Востока, в сентябре 2013 года - Комиссия по вопросам социально-экономического развития Дальнего Востока и Байкальского региона, где ключевым инструментом реализации являются комплексные инвестиционные проекты (КИПы). Развитие Сибири и Дальнего Востока было объявлено руководством страны национальным приоритетом на весь XXI век.

В апреле 2014 года Министерство по развитию Дальнего Востока приступило к корректировке программы, где на смену КИПам пришли территории опережающего развития (ТОРы), а масштабы бюджетного финансирования были уменьшены в 10 раз. Эту версию обеспечил №473-Ф3 «О территориях опережающего социально-экономического развития в Российской Федерации». В официальных документах ТОРы видоизменялись в ТОСЭРы и обратно, что свидетельствует о недостаточном понимании того, что и каким образом законодатель считает нужным регулировать.

В редакции ФЦП «Экономическое и социальное развитие Дальнего Востока и Байкальского региона на период до 2025 г.», принятой в 2014 году появилась идея создания ТОР, позже вышел федеральный закон о ТОСЭР. Для резидентов ТОР пре- дусмотрен более широкий набор льгот по сравнению с ОЭЗ. Например, снижение ставки по налогу на прибыль от 0 до $5 \%$ в течение 5 лет после получения первой прибыли, снижение ставки по налогу на добычу полезных ископаемых, снижение ставок обязательных платежей по страховым взносам до 7,6\% в течение 10 лет с момента получения статуса резидента, освобождение от уплаты налогов на имущество и землю. Для компаний наибольшую привлекательность имеют последние две льготы, т.к. налог на имущество является постоянной статьей затрат, которая увеличивает нагрузку на бизнес. Перенос же действующих предприятий на ТОР невозможен, минимальный объем инвестиций должен составлять 500 тыс. рублей при наличии инвестиционного проекта высокой степени проработки. В 2015-2016 годах были одобрены ТОРы «Хабаровск», «Комсомольск», «Надеждинская», «Большой Камень», «Михайловская», которые успешно функционируют. ТОР «Надеждинская» представляет собой мультимодальный транспортно-логистический комплекс с большим объемом привлекаемых инвестиций, достигающих 37 млрд. рублей, лишь $10 \%$ будут бюджетными. На сельском хозяйстве и пищевом производстве специализируется ТОР «Михайловская» с общим объемом инвестиций в 45 млрд. рублей, из них бюджетных также лишь $10 \%$. Кластер строительных материалов, пищевой промышленности и сельского хозяйства «Ракитное», центр машиностроения и сельскохозяйственного производства «Авангард», гостиничный, логистический и деловой «Аэропорт» являются секторами ТОР «Хабаровск» с привлекаемым объемом частных инвестиций в 36,7 млрд. рублей, из которых бюджетных планируется 2,36 млрд. рублей. ТОР «Комсо- 
мольск» также состоит из нескольких секторов: «Амурлитмаш»- машиностроительный комплекс, «Парус»-судостроение и авиастроение, «Амурск» - центр деревопереработки; общий объем инвестиций ТОР - 12 млрд. рублей, бюджетных 1,23 млрд. рублей. ТОР «Большой Камень» специализируется на судостроении, в рамках ее функционирования была запущена первая в России специализированная верфь крупнотоннажного судостроения на ОАО «Дальневосточный завод «Звезда», частных инвестиций планируется привлечь 160 млрд. рублей, инфраструктурных - 3,2 млрд. рублей. В планах создание таких ТОР, как «Приамурская» (промышленность, логистика), «Белогорск» (АПК) в Амурской области, «Камчатка» (туристско-рекреационная деятельность, логистика), «Беринговская» (добыча полезных ископаемых) на Чукотке, индустриального парка «Кангалассы» в Якутии.

Немного истории, в 1955 г. французский экономист Ф. Перру ввел концепцию «полюсов роста», согласно которой государственные инвестиционные программы окажут максимальное влияние на региональный рост в том случае, если будут сконцентрированы в ограниченном количестве локаций, имеющий экономический потенциал. Ключевая идея данной концепции в том, что экономическое развитие не распределено равномерно по региону, а сосредоточено в определенных полюсах [3]. В России в 2005 году Министерство регионального развития РФ приняло «Концепцию стратегии социально-экономического развития регионов РФ», идея которой заключалась в том, что необходимо перейти от политики выравнивания социально-экономического развития регионов к политике поляризованного роста, сосредоточив ресурсы в нескольких ключевых регионах-локомотивах, призванных сформировать опорный каркас территории России. В 2000 году академик П. А. Минакир предложил концепцию новой индустриализации Дальнего Востока. Суть ее в пространственном аспекте отображается как система из двух дуг - северная является географическим арсеналом концентрации видов деятельности по эксплуатации природных ресурсов, а южная, соединяющая экономические центры юга Владивосток - Хабаровск - Комсомольск-на-Амуре - Благовещенск, местом концентрации высокотехнологичных перерабатывающих производств и услуг, частично интегрированная в международные технологические цепочки. Реализация концепции предполагала создание комплекса высокотехноло- гичных производств по переработке регионального и транзитного сырья с экспортом и межрегиональным вывозом продукции переработки, формирование высокотехнологичных производственных кластеров (аэрокосмического, судостроительного, нефтяного и газохимического), создание инфраструктурного каркаса, обеспечивающего взаимодействие РФ с АТР, создание системы опорных городов и узлов. Предполагалось, что с формированием южной дуги возникнет т.н. контактная зона с сопредельными экономиками Северо-Восточной Азии. Подобная идея оказалась востребована в КНР, где действовала государственная программа модернизации старой промышленной базы. Система двух промышленных дуг на Дальнем Востоке стала выполнять функцию ресурсной «подкачки» для модернизации промышленной базы КНР.

К слову о различиях ОЭЗ и ТОР, в сентябре 2016 года Правительство досрочно прекратило деятельность ОЭЗ на Дальнем Востоке: портовой зоны «Советская гавань» и туристско-рекреационной зоны на о. Русский, ввиду отсутствия зарегистрированных резидентов. Базовые принципы формирования ОЭЗ практически идентичны ТОР, т.е. за счет бюджетных средств осуществляется развитие инфраструктуры, а компаниям-резидентам предоставляются налоговые, таможенные и прочие льготы. Номинальным заявляемым преимуществом ТОР является более широкий перечень льгот. В целом, режим ОЭЗ снижает издержки до $30 \%$, то ТОР - до $40 \%$. Принципиальная новация ТОР состоит в индивидуальной работе с каждым инвестором. В рамках ТОР государство принимает организационное участие, а ОЭЗ движет сила свободного рынка. Опасения функционирования ТОР вызывает неограниченная квота по привлечению иностранной рабочей силы. Однако, здесь следует вспомнить базовый принцип движения факторов производства: капитал перемещается туда, где может произвести наибольший предельный продукт, который обратно пропорционален предельному продукту труда, в связи с этим, относительно низкооплачиваемая иностранная рабочая сила является важным условием прихода иностранных инвесторов.

«Комсомольский-на-Амуре» - авиационный завод. Предприятие, производящее современные пассажирские реактивные самолеты «Суперджет-100» и занявшее свою нишу на глобальном рынке высокотехнологичной продукции, с перспективами дальнейшего укрепления в ней. Таким образом, КнААЗ является одним из ресурсов, на основе ко- 
торого необходимо организовывать производства, способствующего повышению технологического уровня экономики ДФО. Это может способствовать тому, что технологические связи выйдут за пределы территории предприятий, и дадут толчок к развитию остальной территории региона.

В мировой практике можно найти массу неудачного опыта в создании свободных экономических зон. Главным образом, это касается стран с высокой долей добывающего сектора в экономике, в том числе, и России. Правительственные организации не обладают полным набором необходимых знаний для выполнения задачи успешного функционирования свободой экономической зоны. Действия правительства отвлекает планирование производства и распределение ресурсов, не содействуя техническому прогрессу, в отличие от частного бизнеса.

Частный бизнес должен стать инициатором выбора как местоположения, так и отраслевой специализации свободной экономической зоны, или же органы власти на местном уровне. В первом случае, возможно появление частных СЭЗ, в мире они более успешны, чем государственные. Во втором, делегирование полномочий местным органам власти, которые лучше ориентируются в специфике условий конкретной территории, поможет привести к избежанию ненужных расходов на инфраструктуру при реализации недостаточно продуманных проектов.

Мировой опыт создания СЭЗ предполагает привлечение прямых иностранных инвестиций, снижение безработицы, поддержку стратегии экономического развития или апробацию принципиально новых стратегий. При организации ТОСЭР и свободного порта Владивосток не было соблюдено ни одного из этих принципов. Лучшую практику в мире показывают частные СЭ3, а наши дальневосточные остаются государственными. Создаваемые в нашей стране СЭЗ более привлекательны для отечественных инвестиций, для которых на национальном рынке отсутствуют лучшие альтернативы повышения прибыли. К примеру, СЭЗ в Африке, функционируют благодаря финансовым средствам КНР, но используют природные и трудовые ресурсы, избыточные в африканских странах. Китай на законных основаниях получил право пользования месторождениями природного сырья другого континента и поставки его на свой внутренний рынок. Или же финансовый центр Дубая в ОАЭ, являясь СЭЗ, функционирует в рамках британского права, что позволяет снизить рис- ки и привлечь дополнительных инвесторов, рабочую силу и предпринимателей из-за рубежа. Таким образом, страна с высокой природной рентой снизила риски для инвесторов путем введения в экономическую практику продвинутых институтов развитых стран [2].

Лучшее использование потенциала, закрепление населения, повышение уровня доходов предусматривают комплексные программы развития региона - федеральные целевые программы (ФЦП), как, например, ФЦП «Экономическое и социальное развитие Дальнего Востока и Байкальского региона» до 2025 года. В 2007-2012 годах с привлечением инвестиций извне был реализован крупный проект строительства инфраструктуры для проведения форума АТЭС. Привлечение государственных инвестиций не помогло снизить риски для привлечения капитала в региональную экономику. Поддержку в виде льгот и субсидий получают крупные госкорпорации, реализующие крупные инвестиционные программы. Если обратиться к мировому опыту, то приходим к выводу, что государственные программы способствуют снижению региональных диспропорций тогда, когда они встроены в общую политику по снижению экономических рисков в национальной экономике, созданию конкурентных условий и открытости. Они успешно реализуются в условиях децентрализации власти, являясь мерой по улучшению инвестиционного климата.

Для Восточной Азии характерно такое явление, как синдром «плохой памяти», заключающийся в неуверенности азиатских партнеров относительно необратимости «поворота» на восток. Ведь декларация 1987 г., «поворот» 1991 г. не оправдались, а нынешнее внимание Дальнему Востоку стало уделяться после обострения политических отношений с Европой. Дальневосточный регион должен развиваться комплексно и динамично, стратегически важно развивать и повышать комфортность инфраструктуры для обеспечения мобильности как внутри региона и страны, так и с сопредельными государствами. Уровень медицины и образования нужно планомерно повышать до уровня стран АТР. Это поможет Дальнему Востоку предстать в качестве «посла» России в тихоокеанском сообществе государств.

№ 119-Ф3 «Закон о дальневосточном гектаре» от 1 мая 2016 года призван регламентировать бесплатную раздачу земли на территории Дальнего Востока. Однако, не стоит ожидать высокой эффективности от принятия данной меры, посколь- 
ку, опираясь на опыт других стран, можно сделать вывод, что такие нововведения принесут пользу в том случае, если главной задачей является не удержание населения, а обеспечение перехода к новому виду экономики, более соответствующей низкому уровню населенности региона. В 2018 году данный закон распространился и на территории Забайкальского края и республики Бурятия, вошедших в состав Дальневосточного федерального округа, куда они исторически относились с момента создания Приамурского генерал-губернаторства.

Нашему государству, в первую очередь, нужно определиться с тем, какое приоритетное значение имеет Дальний Восток для страны. Если этот регион - источник природных ресурсов, то все силы в его экономическом развитии должны быть направлены на строительство новых шахт, ГОКов, железных дорог, портов. В данном случае экономика будет эффективна при небольшом количестве населения. Можно рассматривать Дальний Восток как интеграционное встраивание России в АТР, но не в виде обмена угля, нефти и газа на электронику и бытовые товары, а как сотрудничество, в котором заинтересованы многие страны, например, космос, авиация, освоение Мирового океана, взаимодействие национальных культур.

Только определив приоритеты, можно выстраивать долгосрочную стратегию, при которой инвесторам будут понятны намерения, конечные цели и результаты национальной политики. Нужны ответы на проблемные вопросы региона: какой мощности и в какой последовательности должны функционировать порты, какой должна быть специализация судостроения, как провести развитие производств для бесперебойной работы космодрома Восточный и встроить бизнес в эти проекты, каких специалистов готовить в дальневосточных вузах, какие культурные центры необходимы для интеграционных процессов.

Если обратиться к понятию «Тихоокеанская Россия», то под ним подразумевается ориентация экономического потенциала центральных регионов на АТР посредством обустройства дальневосточных площадок, способных обеспечивать высокий уровень конкурентоспособности.

Дальний Восток - это треть территории России, подчиняющаяся законам территориальной организации и механизмов управления как во всей стране. Однако, территориально Чукотский автономный округ сопоставим с целым Приволжским федеральным округом, включающим 14 субъектов федерации. Население всей Чукотки около 50 ты- сяч человек в противовес Приволжского, превышающего его в 600 раз. Но в то же время Чукотский автономный округ - это равноправный субъект, как и 84 других со своим правительственным аппаратом и т.д. Или, например, Хабаровский край, территория которого так же сопоставима с Приволжским федеральным округом, население составляет около 1,3 млн. человек, из них $65 \%$ проживают в Хабаровске и Комсомольске-на-Амуре, вдоль Амура и южнее. В остальной половине края проживает 10,5 тысяч человек, это меньше $1 \%$ населения, треть которого живет в поселке Охотск, который ранее являлся центром управления пространством от Аляски до Калифорнии [3]. Поэтому самый острый вопрос в социальной политике региона: когда и при каких обстоятельствах можно будет обеспечить жителей этих территорий условиями жизни, равными с другими федеральными округами и субъектами федерации.

\section{ВЫВОДЫ И РЕКОМЕНДАЦИИ}

1. Субъектам, обладающим выходом к морю, обеспечено лучшее геополитическое положение, чем внутриконтинентальным соседям. Поэтому, если есть возможность такого обеспечения, то это является более чем целесообразным. Как, например, в случае с Амурской областью, в которой выход к морю может быть обеспечен за счет передачи в ее состав Тугуро-Чумиканского района Хабаровского края.

2. Самостоятельность, полученная Еврейской автономной областью, не позволила ей получить прогресс, поэтому целесообразнее ее вернуть в состав Хабаровского края.

3. Не конкуренция, а сотрудничество - главный принцип в развитии Хабаровска и Владивостока. Каждый из городов поддерживает и дополняет друг друга, выполняя свою собственную функцию. Так, Хабаровск - это центр координации и согласования деятельности субъектов ДФО, так сложилось и географически, и исторически, а не Москва, поэтому Министерство по развитию Дальнего Востока должно находиться именно здесь для быстрого принятия решений. Владивосток, в свою очередь, привлекателен для иностранных представительств, ввиду того, что является открытым портом, поэтому в нем уже открыты консульские учреждения более чем 20 стран, в нем прошли форумы - Восточный экономический и форум АТЭС, a также кинофестиваль стран АТЭС. Владивосток из Восточной Азии привлекает туристов. Поэтому Владивосток должен стать площадкой международных коммуникаций стран Азиатско-Тихооке- 
анского региона с Россией и странами Евросоюза. Таким образом, Хабаровск можно считать столицей Дальнего Востока России, а Владивосток - восточной столицей страны --столицей Тихоокеанской России.

Задача создания мирового города на востоке нашей страны является амбициозной и требует такую пространственную организацию, которая заключается в объединении усилий Хабаровска и Владивостока и максимальной концентрации их ресурсов во Владивостокской агломерации, охватывающей юг Приморского края: 13 муниципальных районов с территорией 23,6 тыс. кв. км и населением в 1,4 млн. человек.

Закон «Об особом миграционном режиме» в границах Владивостокской агломерации позволит привлечь население и организовать инвестиционные проекты по наращиванию пропускной способности Транссиба, развитию новых портов с целью достижения наибольшей привлекательности России для организации грузо- и пассажиропотока в рамках перегона с запада на восток. Реальные перспективы в национальной программе у кластеров судостроения, подводной робототехники, производства морских платформ, в регионе всегда будут востребованы морское машиностроение и металлургия.

4. Основными причинами оттока населения являются невостребованность из-за хозяйственной специализации, снижение уровня социально-инфраструктурной обустроенности, что связано с рассеянностью на огромной территории. Решающим фактором отъезда из региона - экстремальные природные условия в сочетании со сложно обустраиваемым бытом. Пока сохраняется убыль населения, притока извне ждать не следует, необходимо, чтобы коренное население не покидало свой дом, чему должны способствовать государственные льготы, прописанные в документе «Паспорт дальневосточника», действующие только на территории региона. Необходима государственная поддержка в воспроизводстве и воспитании населения. Возможность приравнять к участию в реализации национальной стратегии по развитию Дальнего Востока сам факт проживания в макрорегионе может послужить хорошим стимулом к закреплению здесь населения. Окружение Владивостока недооцененный пока ресурс для развития Владивостокской агломерации и всего Дальнего Востока, ведь в его тысячекилометровом радиусе сконцентрировано население общим количеством более 300 млн. человек. Сейчас всего 10 тыс. сту- дентов обучаются в вузах Дальнего Востока, нужна поддержка как для своих, так и для иностранных студентов.

Итак, основное, что должны осуществить правительственные организации, ответственные за развитие дальневосточного региона, это достижение одинакового уровня жизни населения на всем его пространстве, заключающееся в нахождении оптимальной формы расселения жителей и пространственной организации, определение источников, способствующих росту численности, и условий, обеспечивающих приток населения.

Максимально эффективно использовать приграничное положение субъектов Дальневосточного Федерального округа с экономически развитыми территориями Китая [5].

\section{СПИСОК ЛИТЕРАТУРЫ}

1. Антология экономической мысли на Дальнем Востоке / Вып. 1. Колонизационные процессы в Приамурском крае на рубеже XIX-XX веков. Хабаровск, РИОТИП, 2008. 208 с.

2. Изотов Д.А. Дальний Восток: новации в государственной политике // Эко, 2017, № 4(514), с. 27-44.

3. Исаев А. Г. Территории опережающего развития: новый инструмент региональной экономической политики // Эко, 2017, № 4(514), c. 61-77.

4. Кауфман А. А. Переселение и колонизаџия. СПб., 1905. 349 c.

5. Корневец В. С. О формировании транснациональных и трансграничных регионов // Вестник Воронежского государственного университета. Серия: География. Геоэкология, 2009, № 2, с. 93-96.

6. Крушанов А.И., Кулакова И.Ф., Морозов Б.Н., Сем Ю.А. История Дальнего Востока СССР. Владивосток, 1977. 305 с.

7. Крюков Н. А. Опыт описания землепользования у крестьян-переселенцев Амурской и Приморской областей // Записки Приамурского отдела Императорского Русского Географического Общества, 1896, т. 2, вып. 2, с. 12-13.

8. Минакир П.А. Концепция долговременного развития Дальнего Востока. Владивосток, ДВО АН СССР, 1990. $46 \mathrm{c}$.

9. Минакир П.А., Прокапало О.М. Российский Дальний Восток: экономические фобии и геополитические амбиции // Эко, 2017, № 4 (514), с. 5-26.

10. Минакир П.А. Экономика регионов. Дальний Восток. Москва, ЗАО «Издательство «Экономика»», 2006. $848 \mathrm{c}$.

11. Немчинов В.С. Теоретические вопросы рационального размещения производительных сил // Вопросы экономики, 1961, № 6, с. 3-15.

12. Приамурье: факты, ичифры, наблюдения. Москва, 1908. 922 с. 
13. Регионы России. Социально-экономические показатели 2008. Москва, Росстат, 2008. 900 с.

14. Регионы России. Социально-экономические показатели 2016. Москва, Росстат, 2016. 990 с.
Конфликт интересов: Автор декларирует отсутствие явных и потенциальных конфликтов интересов, связанных с публикацией настоящей статьи.

Поступила в редакиию 25.11.2019

Принята к публикации 26.07.2020

UDC 913

ISSN 1609-0683

DOI: https://doi.org/10.17308/geo.2020.3/3025

\title{
Historical and Geographical Research of the Russian Far East
}

\author{
A.A. Ahremenya ${ }^{凶}$ \\ Transbaikal State University, Russian Federation \\ (30, Aleksandro-Zavodskaya St., Chita, 672039)
}

\begin{abstract}
The purpose of this study is to conduct a historical and geographical analysis of the Russian Far East, to identify the features of the formation of specialization and demographic processes in the region.

At each historical stage, the policy of the region underwent changes in social development, adjusted to changing economic and geopolitical conditions, as well as the policy of the Centre. At present, the development of the Far East is a priority area of the domestic policy of our country, therefore, special regulations are being issued, and a Ministry has been created to lobby the interests of the region.

The main limiting factor for the development of the region can be considered a radically different standard of living of the population throughout its space. It involves finding the optimal form of settlement of residents and spatial organization, determining the sources that contribute to the growth of the population, and the conditions that ensure the influx of the population.

Methods and materials are comparative geographical, descriptive, analytical, inductive, mathematical, statistical, cartographic. The research materials are statistical data of Rosstat, literary sources, funds.

Key words: the Far East, problems of the Far East, Far Eastern hectare, natural resources of the Far East, priority development areas.

For citation: Ahremenya A. A. Historical and geographical research of the Russian Far East. Vestnik Voronezskogo gosudarstvennogo universiteta. Geografia geoekologia, 2020, No. 3, pp. 61-71. (In Russ.) DOI: https://doi.org/10.17308/geo.2020.3/3025
\end{abstract}

\section{REFERENCES}

1. Antologiya ekonomicheskoy mysli na Dal'nem Vostoke [Anthology of economic thought in the Far East]. Ros. acad. Issue 1. Kolonizatsionnye protsessy v Priamurskom krae na rubezhe XIX-XX vekov [Colonization processes in the Amur region at the turn of the XIX-XX centuries]. Khabarovsk, Publ. RIOTIP, 2008. 208 p. (In Russ.)

2. Izotov D. A. Dal'niy Vostok: novatsii v gosudarstvennoy politike [The Far East: innovations in public policy]. Eco, 2017, no. 4 (514), pp. 27-44. (In Russ.)

3. Isaev A. G. Territorii operezhayushchego razvitiya: novyy instrument regional'noy ekonomicheskoy politiki [Territories of advanced development: a new instrument of regional economic policy]. Eco, 2017, no. 4 (514), pp. 6177. (In Russ.)
4. Kaufman A. A. Pereselenie i kolonizatsiya [Resettlement and colonization]. St. Petersburg, 1905. 349 p. (In Russ.)

5. Kornevets V. S. O formirovanii transnatsional'nykh i transgranichnykh regionov [The formation of transnational and cross-border regions]. Vestnik Voronezskogo gosudarstvennogo universiteta. Geografia geoekologia, 2009, no. 2, pp. 93-96. (In Russ.)

6. Krushanov A.I., Kulakova I.F., Morozov B. N., Sem Yu. A. Istoriya Dal'nego Vostoka SSSR [History of the Far East of the USSR]. Vladivostok, 1977. 305 p. (In Russ.)

7. Kryukov N. A. Opyt opisaniya zemlepol'zovaniya u krest'yan-pereselentsev Amurskoy i Primorskoy oblastey [Experience in the description of land use among peasantsmigrants of the Amur and Primorsky regions]. Zapiski Pria-

(C) Ahremenya A. A., 2020

\ Anastasia A. Ahremenya, e-mail: ahri@mail.ru The content is available under Creative Commons Attribution 4.0 License. 
murskogo otdela Imperatorskogo russkogo geograficheskogo obshchestva, 1896, v. 2, no. 2, pp. 12-13. (In Russ.)

8. Minakir P. A. Kontseptsiya dolgovremennogo razvitiya Dal'nego Vostoka [The concept of long-term development of the Far East]. Vladivostok, FEB USSR Academy of Sciences, 1990. 46 p. (In Russ.)

9. Minakir P. A., Prokapalo O. M. Rossiyskiy Dal'niy Vostok: ekonomicheskie fobii i geopoliticheskie ambitsii [The Russian Far East: economic phobias and geopolitical ambitions]. Eco, 2017, no. 4 (514), pp. 5-26. (In Russ.)

10. Minakir P. A. Ekonomika regionov. Dal'niy Vostok [Economy of regions. Far East]. Moscow, ZAO Publishing House "Economics", 2006. 848 p. (In Russ.)

11. Nemchinov V.S. Teoreticheskie voprosy ratsional'nogo razmeshcheniya proizvoditel'nykh sil [The-

Ахременя Анастасия Алексеевна

аспирант Забайкальского государственного университета, г. Чита, Российская Федерация, ORCID: https://orcid.ogr/0000-0001-5643-4666, e-mail: ahri@mail.ru oretical questions of the rational distribution of productive forces]. Problems of Economics. 1961, no. 6, pp. 3-15. (In Russ.)

12. Priamur'e: fakty, tsifry, nablyudeniya [Priamurye]. Moscow, 1908. 922 p. (In Russ.)

13. Regiony Rossii. Sotsial'no-ekonomicheskie pokazateli 2008 [Regions of Russia. Socio-economic indicators 2008]. Moscow, Rosstat Publ., 2008. 900 p. (In Russ.)

14. Regiony Rossii. Sotsial'no-ekonomicheskie pokazateli 2016 [Regions of Russia. Socio-economic indicators 2016]. Moscow, Rosstat Publ., 2016. 990 p. (In Russ.)

Conflict of interests: The author declares no information of obvious and potential conflicts of interest related to the publication of this article.

Received: 25.11.2019

Accepted: 26.07.2020

Anastasia A. Ahremenya

Post-graduate student of the Transbaikal State University, Chita, Russian Federation, ORCID:

https://orcid.ogr/0000-0001-5643-4666, e-mail: ahri@mail.ru 